\title{
GAMBARAN SERUM ELEKTROLIT PADA PASIEN ACUTE MIOCARD INFARK (AMI) DI RUANG INTENSIVE CARDIOVASKULER CARE UNIT (ICVCU) RSUD Dr. MOEWARDI DI SURAKARTA
}

\author{
Rahmadhani Nuzul Putri ${ }^{1}$, Suryanti ${ }^{2}$, Siti Lestari $^{3}$ \\ ${ }_{1,2,3}$ Poltekkes Kemenkes Surakarta Jurusan Keperawatan \\ Diterima : 19 Oktober 2018, Disetujui : 27 Oktober 2018 \\ e-mail : lestaristi68@gmail.com
}

\begin{abstract}
Background: AMI is a myocardial necrosis caused by inadequate blood supply.The cardiac muscle contractility has very important role in pumping blood. Contraction of the heart in pumping blood is regulated by cardiac action potential,such as role is sodium $(\mathrm{Na}+)$ and potassium $(K+)$. AMI is a myocardial necrosis caused by inadequate blood supply. Objective of this research to describe the serum electrolytes such as sodium $(\mathrm{Na}+)$ and potassium $(\mathrm{K}+)$ in patients with AMI who undergoes treatment in ICVCU of Regional General Hospital Dr. Moewardi Surakarta in 2016. Reasearch Methods: This research uses descriptive research. The subject of this research is the patients who is treated in ICVCU of Dr. Moewardi hospital with Acute Myocardial Infarction a number of 57 respondents. The researh was conducted in two months. The sampling techniques is by total sampling. The data collection method uses observation technique. Results: The average of AMI respondents are 41-60 years old in which as much as $57.9 \%$, male respondents are as much as $75.4 \%$, the highest classification of AMI STEMI are 75.4\%, the majority of respondents whose the results of sodium levels are in $<136 \mathrm{mmol} / \mathrm{L}$ (low) are $71.9 \%$, the result of potassium levels which are between 3.3 to $5.1 \mathrm{mmol} / \mathrm{L}$ (normal) are 82.5\%. Conclusion: Average AMI patients are 41-60 years, the majority of respondents is male with the highest classification of AMI STEMI and have the level of sodium is $<136 \mathrm{mmol} / \mathrm{L}$ (low)
\end{abstract}

Keywords: Acute myocardial infarction, levels of Potassium, levels of Sodium.

\section{PENDAHULUAN}

Angka kematian yang disebabkan karena AMI selalu meningkat sejak tahun 1970-an. Menurut World Health Organization (WHO) pada tahun 2008 sebanyak 17,3 juta orang meninggal akibat gangguan kardiovaskuler. The Health Survey for England (Departemen for Health, 2010) mengatakan bahwa $3 \%$ penduduk dewasa menderita angina dan $0,5 \%$ penduduk dewasa telah mengalami AMI dalam 12 bulan terakhir (Gray, 012).
Direktorat Jendral Yanmedik Indonesia meneliti pada tahun 2009, jumlah pasien penyakit jantung yang mengalami rawat inap dan rawat jalan di RS di Indonesia adalah 239.548 jiwa. Kasus terbanyak adalah penyakit iskemik yaitu 110.183 kasus. Menurut Depkes (2011), Case Fatality Rate (CFR) tertinggi terjadi pada AMI sebanyak 13,49 $\%$, kemudian diikuti dengan gagal jantung $13,42 \%$ dan penyakit jantung lainnya $13,49 \%$. Risiko infark miokardium akut 
meningkat pada usia $45-54$ tahun dan 5 kali lebih sering terjadi dibanding wanita (Nasar, 2010).

Melihat dari struktur dan fungsi jantung, kontraktilitas otot jantung sangat berperan penting dalam memompa darah. Kontraksi jantung dalam memompa darah diatur oleh potensial aksi jantung. Potensial aksi merupakan dasar irama jantung dan menunjukkan kelainan yang terjadi. Ion yang berperan dalam potensial aksi adalah natrium $\left(\mathrm{Na}^{+}\right)$dan kalium $\left(\mathrm{K}^{+}\right)$. Besarnya konsentrasi kedua jenis ion ini di dalam cairan ekstraseluler akan berpengaruh penting terhadap fungsi jantung (Guyton \& Hall, 2008). Kelebihan ion natrium akan Kenaikan dan penurunan kadar natrium dan kalium tersebut akan mengganggu kerja jantung dalam memompa darah ke seluruh organ tubuh. Sehingga transportasi oksigen juga akan terganggu. Hal tersebut dapat memperburuk kondisi infark yang terjadi pada pasien AMI, bahkan dapat mengakibatkan komplikasi yang lebih berat.

Hasil dari studi pendahuluan pada tanggal 30 November sampai 9 Desember 2015 terdapat 20 pasien dengan AMI yang dirawat di ICVCU RSUD Dr. Moewardi Surakarta dan dilakukan pengecekan laboratorium darah lengkap termasuk serum elektrolit pada pasien tersebut. Hasil nilai laboratorium natrium dan kalium pada pasien AMI saat itu mengalami kenaikan dan penurunan. Berdasarkan uraian diatas, penulis ingin melakukan penelitian dengan judul Profil Serum Elektrolit pada Pasien Akut Miokard Infark (AMI) yang Menjalani Perawatan di Ruang ICVCU Rumah Sakit Umum Daerah Dr. Moewardi Surakarta.

\section{METODE PENELITIAN}

Desain penelitian ini adalah penelitian deskriptif dengan pendekatan kuantitatif. Variabel yang di teliti pada penelitian ini adalah variabel tunggal. Teknik pengambilan sampel dalam penelitian ini menggunakan teknik total sampling. Populasi dalam penelitian ini adalah pasien dengan Infark Miokard Akut yang sedang menjalani perawatan di Ruang ICVCU RSUD Dr. Moewardi Surakarta pada bulan Maret-April 2016 sesuai dengan kriteria inklusi dan ekslusi.

Kriteria inklusi pada penelitian ini adalah pasien yang mempunyai data hasil laboratorium serum elektrolit (natrium dan kalium).

Sedangkan kriteria eksklusi pada penelitian ini adalah :

1. Pasien yang berumur $<18$ tahun

2. Pasien yang sudah mendapatkan terapi farmakologi berupa antibiotik, laksatif, antitusif, diuretic, kortikosteroid dan analgesik.

3. Pasien AMI yang berobat jalan.

Penelitian ini telah mendapat ethical clearance dari Komisi Etik Penelitian Kesehatan RSUD Dr. Moewardi/ Fakultas Kedokteran Universitas Sebelas Maret Surakarta.

\section{HASIL PENELITIAN}

\section{Usia}

Tabel 1. Distribusi responden berdasarkan usia.

\begin{tabular}{ccc}
\hline Usia & Frekuensi & Persentase \\
\hline$>60$ tahun & 20 & 35.1 \\
$>40-60$ tahun & 33 & 57.9 \\
$18-40$ tahun & 4 & 7.0 \\
\hline Total & 57 & 100.0 \\
\hline \multicolumn{2}{c}{ Responden } & berusia $>60$ tahun \\
sebanyak 235,1 \%, berusia $41-60$ tahun
\end{tabular}


sebanyak 57,9 \%, sedangkan jumlah responden terendah berusia 18 - 40 tahun sebanyak $7 \%$.

Teori yang diungkapkan Muttaqin (2009) mengatakan bahwa AMI 45\% terjadi pada usia 45 tahun keatas. AMI lebih banyak terjadi pada usia 45 tahun keatas disebabkab oleh beberapa faktor seperti, pikiran yang terlalu berat/ tingkat stress, obesitas, hipertensi yang menyebabkan meningkatnya after load yang secara langsung akan meningkatkan beban kerja jantung sehingga memicu hipertrofi ventrikel kiri, yang mengakibatkan ketidakseimbangan antara kebutuhan dan suplai oksigen (Corwin, 2008). Selain karena stres, menurut Sylvia dan Lorraine (2006) peningkatan usia berpengaruh terhadap menurunnya fungsi organ tubuh terutama jantung dan pembuluh darah, sehingga mengganggu absorbsi nutrisi oleh sel - sel endotel yang menyusun lapisan pembuluh darah. Sejalan dengan hasil penelitian yang dilakukan oleh Rendi Dwi Prasetyo, Masrul Syafri \& Efrida bahwa terdapat 55,56\% pasien AMI berusia 40-60 tahun.

\section{Jenis kelamin}

Tabel 2. Distribusi responden berdasarkan jenis kelamin

\begin{tabular}{|c|c|c|}
\hline Jenis Kelamin & Frekuensi & Persentase \\
\hline Perempuan & 14 & 24.6 \\
\hline laki - laki & 43 & 75.4 \\
\hline Total & 57 & 100.0 \\
\hline
\end{tabular}

dengan jenis kelamin laki-laki sebanyak $75,4 \%$ dan untuk perempuan sebanyak $24,6 \%$.

Risiko AMI 5 kali lebih sering terjadi pada laki - laki dibanding wanita (Nasar, 2010). Muttaqin (2009) juga mengungkapkan bahwa AMI banyak terjadi pada laki - laki dibandingkan dengan perempuan. Hal ini dipengaruhi oleh gaya hidup seperti stress tinggi, merokok yang mengakibatkan aterosklerosis sehingga meningkatkan kebutuhan oksigen jantung dan menurunkan kapasitas pengangkutan oksigen.

Teori yang lain menyebutkan bahwa laki - laki rentan terhadap terjadinya AMI dibandingkan perempuan dikarenakan perempuan memiliki hormon estrogen, dimana hormone tersebut melindungi dinding pembuluh darah dari lemak yang menyebabkan penyumbatan pada pembuluh darah (Hananto, 2006). Hasil penelitian ini sejalan dengan penelitian yang dilakukan oleh Budi Widiyanto dan L.S Yamin yang menyatakan bahwa berdasarkan jenis kelamin menunjukan bahwa tertinggi adalah laki-laki yaitu $76,3 \%$ dan disusul oleh perempuan $23,7 \%$. Penelitian Rendi Dwi Prasetyo, Masrul Syafri \& Efrida juga menunjukkan bahwa jenis kelamin terbanyak pasien AMI adalah laki-laki sebanyak $72,22 \%$

\section{Klasifikasi Infark Miokard Akut}

Tabel 3. Distribusi responden berdasarkan klasifikasi Infark Miokard Akut

Klasifikasi

Infark Miokard Frekuensi Persentase Akut

\begin{tabular}{lll}
\hline NSTEMI & 14 & $24.6 \%$ \\
STEMI & 43 & $75.4 \%$ \\
Total & 57 & $100 \%$ \\
\hline
\end{tabular}

Dari tabel di atas didapatkan responden dengan STEMI sebanyak $75,4 \%$ dan responden dengan NSTEMI sebanyak $24,6 \%$.

Penelitian yang dilakukan oleh Dani \& Gunawan Dani dan Gunawan 
tahun 2012 yang menunjukkan angka kejadian STEMI $64,7 \%$ dan NSTEMI $35,3 \%$. Angka kejadian STEMI lebih tinggi juga dibuktikan oleh penelitian Dewi, Dwi Susi dan Sumardino tahun 2014 yang menunjukkan responden dengan STEMI sebanyak 54,7\% dan NSTEMI 43,3\%.

Sedangkan menurut Perhimpunan Dokter Spesialis Kardiovaskuler Indonesia (2009) menambahkan, prevalensi pasien NSTEMI lebih tinggi dibandingkan STEMI. Beberapa penelitian menunjukkan hasil yang berbeda. Hal tersebut disebabkan karena adanya perbedaan tempat dan waktu pengambilan data.

\section{Kadar Natrium}

Tabel 4. Distribusi responden berdasarkan kadar natrium

\begin{tabular}{lcc}
\hline Kadar Natrium & Frekuensi & Persentasi \\
\hline $\begin{array}{l}\text { Rendah } \\
(<136 \mathrm{mmol} / \mathrm{L})\end{array}$ & 41 & 71.9 \\
$\begin{array}{l}\text { Normal }(136- \\
145 \mathrm{mmol} / \mathrm{L})\end{array}$ & 16 & 28.1 \\
\hline \multicolumn{2}{l}{ Total Kadar natrium rendah } & sebanyak
\end{tabular}

$71,9 \%$, sedangkan kadar natrium normal sebanyak $28,1 \%$ dan tidak ada responden dengan kadar natrium tinggi.

Konsentrasi natrium normal dalam kompartemen ekstraseluler diatur oleh mekanisme hormon antidiuretik dan aldosteron. Salah satu fungsi natrium dalam tubuh selain membantu mempertahankan keseimbangan air, asam dan basa dalam cairan ekstraseluler yaitu berperan penting dalam kontraksi otot dan fungsi syaraf (Tamsuri, 2009).

$$
\text { Elektrolit serum dapat }
$$
mempengaruhi prognosis klien dengan AMI atau setiap kondisi gangguan jantung (Muttaqin, 2009). Natrium mungkin hilang melalui muntah, diare, keringat atau mungkin disebabkan oleh penggunaan diuretik, terutama pada seseorang yang melakukan diet rendah garam (Smeltzer \& Bare, 2008). Konsentrasi natrium yang sangat rendah, seperti yang terdapat pada introksikasi air, sering menyebabkan kematian karena fibrilasi jantung (Guyton, 2008). Sejalan dengan penelitian Qing Tang dan Qi Hua, mengatakan bahwa hiponatremi berpengaruh besar terhadap prognosis buruk pada pasien dengan stemi dan angka kematian meningkat pada pasien dengan hiponatremi. Penelitian yang dilakukan oleh Adelin juga menyebutkan bahwa hiponatremi merupakan faktor prediktor kuat terhadap kejadian Major Adverse cardiovascular Event (MACE) pada pasien IMA.

Kadar natrium yang rendah atau hiponatremi terjadi karena defisiensi aldosterone seperti yang terjadi pada insufisiensi adrenal. Pada pasien gangguan jantung insufisiensi adrenal terjadi akibat mekanisme kompensasi yang berlebihan. Adanya gangguan atau kelemahan jantung dalam memompa darah mengakibatkan terjadinya penurunan curah jantung. Penurunan curah jantung akan menimbulkan mekanisme kompensasi berupa aktivitas system simpatis dan sistem renin angiotensin aldosterone yang merupakan mekanisme tubuh untuk mempertahankan perfusi ke jaringan vital. Mekanisme kompensasi tersebut akan memperburuk keadaan jantung apabila terlalu berlebihan. Penurunan curah jantung yang terjadi dapat mengakibatkan vasokontriksi pembuluh darah, sehingga terjadi kurangnya perfusi organ, termasuk menurunnya perfusi ginjal. 


\section{Kadar Kalium}

Tabel 5. Distribusi responden berdasarkan kadar Kalium

\begin{tabular}{lcc}
\hline \multicolumn{1}{c}{ Kadar Kalium } & Frekuensi & Persentasi \\
\hline $\begin{array}{l}\text { Rendah }(<3,3 \\
\text { mmol/L) }\end{array}$ & 6 & 10.5 \\
$\begin{array}{l}\text { Normal }(3,3- \\
5,1 \mathrm{mmol} / \mathrm{L})\end{array}$ & 47 & 82.5 \\
$\begin{array}{l}\text { Tinggi }(> \\
5,1 \mathrm{mmol} / \mathrm{L})\end{array}$ & 4 & 7.0 \\
\hline Total & 57 & 100.0 \\
\hline
\end{tabular}

Dari data tabel 3.5 menunjukkan jumlah responden dengan kadar kalium rendah sebanyak $10,5 \%$, sedangkan untuk kadar kalium normal sebanyak $82,5 \%$ dan responden dengan kadar kalium tinggi sebanyak $7 \%$.

Kalium mempengaruhi aktivitas baik otot skelet maupun otot jantung. Pada penelitian didapatkan sebagian besar responden yang mengalami AMI mempunyai kadar kalium normal. Jika kadar kalium masih dalam rentang normal, hal tersebut juga dapat membuktikan tidak adanya perubahan kelistrikan jantung dan menunjukkan kondisi yang masih stabil . Sejalan dengan teori Hudak (2012) bahwa di dalam sel jantung, kalium dengan nilai kadar normal berperan penting pada kondisi repolarisasi dan depolarisasi dalam mempertahankan kondisi stabil.

Perubahan dalam konsentrasinya mengubah iritabilitas dan ritme miokardia (Smeltzer \& Bare, 2008). Penurunan kadar kalium dapat menujukkan kelainan kerja atau kelistrikan jantung pada pasien AMI. Menurut Smeltzer \& Bare (2008) bahwa perubahan nilai kadar kalium menimbulkan perubahan - perubahan yang khas pada elektrokardiogram dimana elektrokardiogram mencerminkan peristiwa - peristiwa kelistrikan jantung
Menurut Smeltzer \& Bare (2008), meskipun jarang terjadi kenaikan kadar kalium lebih berbahaya karena henti jantung lebih sering dihubungkan dengan kondisi kenaikan kadar kalium. Peningkatan konsentrasi kalium hanya 8$12 \mathrm{mEq} / \mathrm{liter}$ atau 2 sampai 3 kali normal biasanya akan menyebabkan kelemahan jantung sehingga akan menyebabkan kematian (Guyton, 2008). Seperti pada penurunan kalium, kenaikan kalium sering terjadi karena rangsangan pengobatan. Oleh karena itu sebelum memberikan penatalaksaan perawat harus menyadari dan lebih teliti penyebab dari kenaikan kadar kalium yang terjadi

Penelitian ini hanya bersifat kuantitatif karena hanya menjabarkan persentase variable penelitian secara umum sehingga perlu diadakan penelitian lebih mendalam tentang kadar elektrolit serum pada pasien dengan gangguan jantung khususnya Akut Miokard Infark.

\section{PEMBAHASAN}

1. Tingkat Usia pada Pasien AMI

$$
\text { Berdasarkan tabel 4.1, }
$$

sebagian besar dari 57 responden terdiagnosis AMI berusia 41 - 60 tahun yaitu sebanyak 57,9 \%. Hal ini sesuai dengan teori yang dikemukakan oleh Nasar (2010) bahwa risiko AMI meningkat pada usia 45 - 54 tahun. Teori yang diungkapkan Muttaqin (2009) mengatakan bahwa AMI 45\% terjadi pada usia 45 tahun keatas. AMI lebih banyak terjadi pada usia 45 tahun keatas disebabkab oleh beberapa faktor seperti, pikiran yang terlalu berat/ tingkat stress, obesitas, hipertensi yang menyebabkan meningkatnya after load yang secara langsung akan meningkatkan beban kerja jantung sehingga memicu hipertrofi ventrikel kiri, yang 
mengakibatkan ketidakseimbangan antara kebutuhan dan suplai oksigen (Corwin, 2008). Sebagai contoh, pada rentang usia tersebut didalam tahap perkembangan keluarga tugas dan tanggungjawab yang dimiliki cukup berat karena sebagai orang tua yang mulai melepas otoritasnya dan membimbing anak untuk bertanggung jawab. Biasanya hal tersebut menimbulkan konflik batin pada orang tua sehingga menyebabkan adanya stress berat. Selain karena stres, menurut Sylvia dan Lorraine (2006) peningkatan usia berpengaruh terhadap menurunnya fungsi organ tubuh terutama jantung dan pembuluh darah, sehingga mengganggu absorbsi nutrisi oleh sel - sel endotel yang menyusun lapisan pembuluh darah. Penurunan fungsi organ-organ dalam tubuh termasuk jantung sehingga arteri koroner mengalami vasokonstriksi kemudian terjadi gangguan aliran darah ke miokard yang akan menyebabkan nekrosis otot jantung. Sejalan dengan hasil penelitian yang dilakukan oleh Rendi Dwi Prasetyo, Masrul Syafri \& Efrida bahwa terdapat $55,56 \%$ pasien AMI berusia $40-$ 60 tahun.

AMI juga bisa terjadi pada usia < 40 tahun seperti pada tabel 4.1 terdapat $7 \%$ responden dengan rentang usia 18 40 tahun. Sejalan dengan penelitian Rendi Dwi Prasetyo, Masrul Syafri, dan Efrida yang menunjukkan bahwa terdapat 6 responden $(11,11 \%)$ pasien AMI yang berusia $<40$ tahun. Penelitian Purnomo dan Heri juga menunjukkan terdapat responden AMI yang berusia <40 tahun, yaitu 5 responden $(8,8 \%)$ berusia 31 - 40 tahun, $1 \mathrm{r}$ esponden $(1,8 \%)$ berusia $21-30$ tahun. Hal ini terjadi dimungkinkan karena adanya pengaruh oleh gaya hidup, salah satunya yaitu kurangnya aktivitas gerak pada usia muda. Dalam hubungannya dengan penyakit jantung, telah dilaporkan bahwa orang yang tidak aktif memiliki resiko 1,9 kali lebih besar untuk menderita penyakit jantung dibandingkan mereka yang aktif berolahraga (Peter Kabo, 2008). Olahraga dengan teratur dapat meningkatkan kemampuan jantung untuk memompa dan dapat menurunkan kadar kolesterol. Kadar kolesterol tinggi dalam tubuh dan terjadi dalam waktu yang lama mengakibatkan terbentuknya aterosklerosis yang akan mengakibatkan adanya penyempitan arteri koroner atau penyempitan total arteri oleh thrombus sehingga menurunkan kapasitas pengangutan oksigen ke organ tubuh. Hal ini mengakibatkan jantung bekerja lebih keras untuk memompa darah keseluruh tubuh agar kebutuhan oksigen pada organ tercukupi (Muttaqin, 2009; Smeltzer \&Suzane, 2009). Sesuai dengan penelitian Fitri Rusydiana Tsani yang menyebutkan bahwa responden yang tidak memiliki kebiasaan olahraga mempunyai resiko 4,889 kali terkena penyakit jantung koroner dibandingkan responden yang memiliki kebiasaan olahraga.

AMI dapat terjadi pada beberapa kelompok usia. Tidak hanya menyerang pada usia dewasa lanjut namun juga beresiko pada usia dewasa awal. Walaupun jumlahnya tidak sebanyak pada usia dewasa madya dan dewasa lanjut namun tetep beresiko. Oleh karena itu penting bagi perawat dan pasien mengetahui beberapa faktor yang menyebabkan hal itu dapat terjadi. Pencegahan dapat dilakukan lebih dini 
jika kita mengetahui faktor yang mempengaruhi.

2. Jenis Kelamin Pasien AMI

Hasil dari penelitian 57 responden menunjukkan lebih banyak responden berjenis kelamin laki- laki. Hal ini dibuktikan dengan distribusi frekuensi jumlah pada responden laki laki ada 43 responden $(75,4 \%)$, sedangkan perempuan ada 14 responden $(24,6 \%)$. Dapat disimpulkan bahwa laki - laki cenderung lebih beresiko dibanding dengan perempuan. Menurut literatur risiko AMI 5 kali lebih sering terjadi pada laki - laki dibanding wanita (Nasar, 2010). Muttaqin (2009) juga mengungkapkan bahwa AMI banyak terjadi pada laki - laki dibandingkan dengan perempuan. Hal ini dipengaruhi oleh gaya hidup seperti stress tinggi, merokok yang engakibatkan aterosklerosis sehingga meningkatkan kebutuhan oksigen jantung dan menurunkan kapasitas pengangkutan oksigen. Teori yang lain menyebutkan bahwa laki - laki rentan terhadap terjadinya AMI dibandingkan perempuan dikarenakan perempuan memiliki hormon estrogen, dimana hormone tersebut melindungi dinding pembuluh darah dari lemak yang menyebabkan penyumbatan pada pembuluh darah (Hananto, 2006). Hasil penelitian ini sejalan dengan penelitian yang dilakukan oleh Budi Widiyanto dan L.S Yamin yang menyatakan bahwa berdasarkan jenis kelamin menunjukan bahwa tertinggi adalah laki-laki yaitu 76,3\% dan disusul oleh perempuan $23,7 \%$. Penelitian Rendi Dwi Prasetyo, Masrul Syafri \& Efrida juga menunjukkan bahwa jenis kelamin terbanyak pasien AMI adalah laki-laki sebanyak $72,22 \%$.
Laki - laki mempunyai resiko lebih tinggi terkena AMI dibanding perempuan, namun bukan berarti perempuan tidak mempunyai resiko. Beberapa penelitian juga menemukan bahwa perempuan juga beresiko walaupun angka kejadiannya lebih kecil. Namun, menurut hasil pembahasan diatas, dapat diperkirakaan resiko AMI pada perempuan akan meningkat pada usia menopause karena adanya penurunan produksi hormon.

3. Klasifikasi Diagnosa Medis pada Pasien AMI

Hasil dari penelitian 57 responden didapatkan responden dengan STEMI sebanyak 43 responden $(75,4 \%)$, sedangkan dengan NSTEMI sebanyak 14 responden $(24,6 \%)$. Hal itu sejalan dengan penelitian yang dilakukan oleh Dani dan Gunawan tahun 2012 yang menunjukkan angka kejadian STEMI $64,7 \%$ dan NSTEMI 35,3 \%. Angka kejadian STEMI lebih tinggi juga dibuktikan oleh penelitian Dewi, Dwi Susi dan Sumardino tahun 2014 yang menunjukkan responden dengan STEMI sebanyak $54,7 \%$ dan NSTEMI $43,3 \%$.

Menurut Sjaharudin dan Alwi dalam Sudoyo (2009), dari 5,3 juta kunjungan ke IGD / tahun 1/3 darinya disebabkan oleh UA/NSTEMI dan merupakan penyebab tersering kunjungan ke rumah sakit pada penyakit jantung. Angka kunjungan RS untuk pasien UA/NSTEMI semakin meningkat sementara angka AMI dengan STEMI menurun. Perhimpunan Dokter Spesialis Kardiovaskuler Indonesia (2009) menambahkan, prevalensi pasien NSTEMI lebih tinggi dibandingkan STEMI. Beberapa penelitian menunjukkan hasil yang berbeda. Hal 
tersebut disebabkan karena adanya perbedaan tempat dan waktu pengambilan data.

4. Kadar Natrium pada Pasien AMI

Hasil dari penelitian 57 responden didapatkan data kadar natrium terbanyak berada pada nilai < 136 $\mathrm{mmol} / \mathrm{L}$ (rendah) sebanyak 41 responden $(71,9 \%)$ dan yang lainnya diantara 136 - $145 \mathrm{mmol} / \mathrm{L}$ (normal) sebanyak 16 responden $(28,1 \%)$. Konsentrasi natrium normal dalam kompartemen ekstraseluler diatur oleh mekanisme hormon antidiuretik dan aldosteron. Salah satu fungsi natrium dalam tubuh selain membantu mempertahankan keseimbangan air, asam dan basa dalam cairan ekstraseluler yaitu berperan penting dalam kontraksi otot dan fungsi syaraf (Tamsuri, 2009).

Elektrolit serum dapat mempengaruhi prognosis klien dengan AMI atau setiap kondisi gangguan jantung (Muttaqin, 2009). Natrium mungkin hilang melalui muntah, diare, keringat atau mungkin disebabkan oleh penggunaan diuretik, terutama pada seseorang yang melakukan diet rendah garam (Smeltzer \& Bare, 2008). Konsentrasi natrium yang sangat rendah, seperti yang terdapat pada introksikasi air, sering menyebabkan kematian karena fibrilasi jantung (Guyton, 2008). Sejalan dengan penelitian Qing Tang dan Qi Hua, mengatakan bahwa hiponatremi berpengaruh besar terhadap prognosis buruk pada pasien dengan stemi dan angka kematian meningkat pada pasien dengan hiponatremi. Penelitian yang dilakukan oleh Adelin juga menyebutkan bahwa hiponatremi merupakan faktor prediktor kuat terhadap kejadian Major
Adverse cardiovascular Event (MACE) pada pasien IMA.

Kadar natrium yang rendah atau hiponatremi terjadi karena defisiensi aldosterone seperti yang terjadi pada insufisiensi adrenal. Pada pasien gangguan jantung insufisiensi adrenal terjadi akibat mekanisme kompensasi yang berlebihan. Adanya gangguan atau kelemahan jantung dalam memompa darah mengakibatkan terjadinya penurunan curah jantung. Penurunan curah jantung akan menimbulkan mekanisme kompensasi berupa aktivitas system simpatis dan sistem renin angiotensin aldosterone yang merupakan mekanisme tubuh untuk mempertahankan perfusi ke jaringan vital. Mekanisme kompensasi tersebut akan memperburuk keadaan jantung apabila terlalu berlebihan. Penurunan curah jantung yang terjadi dapat mengakibatkan vasokontriksi pembuluh darah, sehingga terjadi kurangnya perfusi organ, termasuk menurunnya perfusi ginjal.

Penting artinya bagi perawat untuk mengidentifikasi pasien yang beresiko terhadap nilai kadar natrium yang rendah sehingga dapat dilakukan pemantauan yang lebih intensif. Pengganti natrium dapat diberikan pemberian natrium secara hati - hati (Smeltzer \& Bare, 2008 ). Pemberian ini dapat diberikan melalui oral, selang nasogastrik atau secara parenteral. Bagi pasien yang mampu makan atau minum, penggantian natrium dapat dilakukan dengan mudah dengan mengkonsumsi diet normal. Namun, bagi pasien yang tidak mampu menerima natrium per oral, larutan Ringer Laktat atau saline isotonis $(0,9 \%$ natrium klorida $)$ mungkin diberikan. Saat pemberian 
cairan pada pasien yang mempunyai gangguan kardiovaskuler, perawat harus memantau pasien terhadap tanda- tanda kelebihan beban sirkulasi, seperti adanya krekels dengan melakukan auskultasi paru. Jika nilai natrium yang rendah terjadi pada pasien dengan volume cairan normal atau berlebih, penanganan dapat dilakukan dengan pembatasan cairan (Smeltzer \& Bare, 2008).

Bagi tenaga medis khususnya perawat penting untuk melakukan pemantauan pada pasien AMI yang mengalami perubahan kadar natrium. Pemantauan dilakukan untuk mencegah terjadinya komplikasi yang lebih berat dan memperberat kerja jantung. Selain menghindari keparahan infark pada jantung juga mencegah pasien dari komplikasi yang mungkin terjadi karena ketidakseimbangan cairan dan elektrolit pada pasien AMI. Namun jika pada saat pemeriksaan pasien sudah menunjukkan tanda - tanda adanya kelebihan cairan seperti adanya oedema dan bunyi krekels pada saat dilakukan pemeriksaan fisik, maka pemeriksaan lanjutan perlu dilakukan dan dapat menegakkan diagnose keperawatan gangguan kelebihan cairan dan elektrolit. Sehingga penatalaksanaan dapat segera dilakukan, sepeti memantau tanda - tanda vital pasien, memantau masukan dan keluaran cairan pada pasien.

5. Kadar Kalium pada Pasien AMI

Hasil dari penelitian 57 responden didapatkan data kadar kalium terbanyak berada antara 3,3 - 5,1 $\mathrm{mmol} / \mathrm{L}$ (normal) sebesar 47 responden $(82,5 \%)$, hasil kadar kalium $<3,3 \mathrm{mmol} / \mathrm{L}$ (rendah) sebesar 6 responden $(10,5 \%)$ dan yang mempunyai hasil kadar kalium $>5,1$
mmol/L (tinggi) sebesar 4 responden (7\%). Kalium merupakan suatu elektrolit dan mineral yang berfungsi untuk menjaga keseimbangan air (sejumlah cairan di dalam maupun di luar sel tubuh) dan elektrolit di dalam tubuh, serta berperan penting dalam fungsi kerja saraf dan kontraksi otot (Irianto, 2014). Kalium mempengaruhi aktivitas baik otot skelet maupun otot jantung. Pada penelitian didapatkan sebagian besar responden yang mengalami AMI mempunyai kadar kalium normal. Jika kadar kalium masih dalam rentang normal, hal tersebut juga dapat membuktikan tidak adanya perubahan kelistrikan jantung dan menunjukkan kondisi yang masih stabil . Sejalan dengan teori Hudak (2012) bahwa di dalam sel jantung, kalium dengan nilai kadar normal berperan penting pada kondisi repolarisasi dan depolarisasi dalam mempertahankan kondisi stabil.

Pada hasil penelitian terdapat 6 responden $(10,5 \%)$ yang memiliki kadar kalium $<3,3 \mathrm{mmol} / \mathrm{L}$ (rendah). Perubahan dalam konsentrasinya mengubah iritabilitas dan ritme miokardia (Smeltzer \& Bare, 2008). Penurunan kadar kalium dapat menujukkan kelainan kerja atau kelistrikan jantung pada pasien AMI. Menurut Smeltzer \& Bare (2008) bahwa perubahan nilai kadar kalium menimbulkan perubahan - perubahan yang khas pada elektrokardiogram dimana elektrokardiogram mencerminkan peristiwa - peristiwa kelistrikan jantung. Sejalan dengan teori yang dikatakan oleh Price (2005) bahwa gangguan irama jantung atau disritmia merupakan jenis komplikasi tersering pada Akut Miokard Infark. Aritmia terjadi akibat elektrofisiologi sel - sel 
miokardium. Beratnya aritmia berhubungan dengan penurunan kadar kalium sehingga memerlukan pengenalan dini dari masalah ini (Hudak, 2012). Hal ini sesuai dengan penelitian Taysir $S$ Garadah, Salah Kassab, Jamal Golbahar yang menyebutkan bahwa hipokalemia mempengaruhi keparahan aritmia pada pasien dengan AMI.

Kehilangan kalium pada AMI mungkin juga disebabkan karena adanya muntah. Sesuai dengan teori bahwa manisfestasi klinis pasien AMI terjadi mual muntah yang mungkin berkaitan dengan nyeri hebat (Corwin, 2009). Sedangkan kehilangan kalium melalui gastrointestinal merupakan penyebab yang paling sering dari penurunan kadar kalium. Muntah dan pengisapan gastrik seringkali menyebabkan terjadinya penurunan kadar kalium (Smeltzer \&Bare, 2008).

Penanganan terhadap adanya penurunan kadar kalium pada pasien yang paling baik adalah pencegahan. Kehilangan kalium harus diperbaiki setiap hari, pemberian kalium sebanyak 40 sampai $80 \mathrm{meq} / \mathrm{L}$ sudah adekuat untuk orang dewasajika tidak ada kehilangan kalium yang abnormal. Untuk pasien yang berisiko, harus disediakan diet yang mengandung cukup kalium, masukan harian kalium pada orang dewasa rata - rata adalah 50 - 100 meq/hari (Smeltzer \& Bare, 2008). Sebagai perawat kita juga harus memperhatikan asupan makanan pada pasien. Makanan yang mengandung tinggi kalium diantaranya pisang, avokad, kacang - kacangan, dan kentang. Jika masukan makanan tidak adekuat perawat dapat melakukan kolaborasi dengan dokter dengan pemberian tambahan kalium.
Hasil penelitian juga menunjukkan responden dengan hasil kadar kalium >5,1 $\mathrm{mmol} / \mathrm{L}$ (tinggi) sebesar 4 responden (7\%). Ini menunjukkan bahwa pada pasien AMI kenaikan kadar kalium lebih jarang terjadi. Sesuai dengan teori Smeltzer \& Bare (2008), meskipun jarang terjadi kenaikan kadar kalium lebih berbahaya karena henti jantung lebih sering dihubungkan dengan kondisi kenaikan kadar kalium. Peningkatan konsentrasi kalium hanya $8-12 \mathrm{mEq} /$ liter atau 2 sampai 3 kali normal biasanya akan menyebabkan kelemahan jantung sehingga akan menyebabkan kematian (Guyton, 2008). Seperti pada penurunan kalium, kenaikan kalium sering terjadi karena rangsangan pengobatan. Oleh karena itu sebelum memberikan penatalaksaan perawat harus menyadari dan lebih teliti penyebab dari kenaikan kadar kalium yang terjadi. Sejauh ini efek dari kenaikan kadar kalium yang paling penting secara klinis adalah efeknya pada miokardium. Biasanya akan terjadi konduksi jantung jika kadar kalium mencapai $8 \mathrm{mmol} / \mathrm{L}$. Perubahan paling dini, sering terjadi pada kadar kalium lebih tinggi dari $6 \mathrm{mmol} / \mathrm{L}$. Hal ini sejalan dengan penelitian yang dilakukan oleh Idha Dwi Kartikasari, yang membuktikan bahwa nilai kadar kalium yang tinggi pada pasien gagal ginjal kronis akan mempengaruhi kejadian aritmia. Begitu juga dengan penelitian Anna, Abhinav, Kensey, Peter, Greg Fonarow etc menghasilakan bahwa ada peningkatan mortalitas dengan nilai kalium yang lebih tinggi, terutama pada pasien non dialisis, dengan peningkatan yang ditandai dengan kematian bahkan pada keadaan tingkat hiperkalemia yang masih rendah. 


\begin{abstract}
Bagi tenaga medis khususnya perawat penting untuk melakukan pemantauan pada pasien AMI yang mengalami perubahan kadar elektrolit salah satunya saitu kalium. Prosedur EKG segera dilakukan untuk mendeteksi perubahan. Repolarisasi yang memendek dan gelombang $\mathrm{T}$ tinggi sering terlihat pada awalnya, selain itu juga perlu dilakukan pemeriksaan ulang terhadap nilai kadar natrium untuk penanganan selanjutnya.pada situasi non akut pembatasan pada diet kalium mungkin cukup membantu. Pada keadaan darurat, dapat diberikan kolaborasi pemberian kalsium glukonat secara intravena, kalsium bekerja secara antagonis melawan aksi hyperkalemia pada jantung (Smeltzer \& Bare,008).
\end{abstract}

Perubahan konsentrasinya sangat berpengaruh terhadap sistem fisiologis tubuh. Penurunan maupun kenaikan nilai pada kadar kalium ternyata sangat berpengaruh besar terhadap kerja jantung. Seperti halnya pada pasien dengan perubahan kadar natriumnya. Oleh karena itu perlu bagi perawat pada pasien, termasuk kadar elektrolit pada pasien dengan gangguan pada jantung dalam hal ini adalah pasien AMI. Penanganan lebih dini sangat diperlukan untuk mengurangi resiko prognosis pasien yang lebih lanjut. khususnya perawat kritis untuk lebih memperhatikan dan memantau perubahan - perubahan yang terjadi

\section{KESIMPULAN DAN SARAN}

Berdasarkan kharakteristik Infark Miokard Akut banyak terjadi pada usia $>41$ - 60 tahun, responden berjenis kelamin laki-laki lebih banyak, responden dengan klasifikasi IMA STEMI lebih banyak dari NSTEMI.

1. Sebagian besar responden mempunyai nilai kadar natrium rendah.

2. Kadar kalium menunjukkan hasil terbanyak dalam rentang normal.

Bagi Pasien dan Keluarga, Diharapkan dapat digunakan oleh pasien dan keluarga sebagai pengetahuan dan sumber informasi dalam mencegah komplikasi AMI., Bagi Perawat, Melihat pentingnya pengaruh nilai kadar natrium dan kalium pada pasien AMI, hal ini dapat digunakan perawat guna menambah wawasan serta memberikan pemahaman tentang gambaran elektrolit agar lebih memperhatikan hasil laboratorium kadar elektrolit khususnya natrium dan kalium pada AMI di Ruang ICVCU RSUD Dr. Moewardi dan Bagi Peneliti Selanjutnya perlu dilakukan penelitian lebih lanjut tentang kadar elektrolit responden akut miokard infark dengan jumlah sampel yang lebih besar, serta dilakukan dibeberapa rumah sakit di daerah yang berbeda dan menggali lebih dalam mengenai hubungan ataupun pengaruh kadar elektrolit pasien AMI terhadap fungsi organ yang lain.

\section{DAFTAR RUJUKAN}

Adeline. (2015). Hubungan Kadar Natrium dengan Kejadian Major Adverse Cardiovascular Event pada pasien Infark Miokard Akut.

Arikunto, S. (2010). Prosedur Penelitian Suatu Pendekatan Praktik. Jakarta: RingkasanCipta.

Carpenito, L. J. (2008). Buku Saku Diagnosis Keperawatan Edisi 10. Jakarta: EGC.

Corwin, E. J. (2009). Buku Saku Patofisiologi edisi 3. Jakarta: EGC. 
Departemen Kesehatan RI. (2011). Profil Kesehatan Indonesia 2011.Tersedia di http:// www.depkes.go.id/download/pub likasi/diakses pada 11 Januari 2015.

DwiKartikasari, Idha. (2009). Hubungan antara Hiperkalemia pada Pasien Gagal Ginjal Kronik dengan Timbulnya Aritmia di RSUD Kab Jombang PeriodeJanuari - Juni 2009. Other Thesis, Unniversity of Muhammadiyah Malang.

Garadah, Tasyir S., Salah Kassab., Jamal Galbahar. (2010). Association of Hypokalemia with Severe Arrhytmias in Patients with Acute Miocardial Infarction. Bahrain Medical Bulleti, vol 33.

Grodzinsky, Anna., Abhinav Goyal, etc. (2014) Prevalence and Prognosis of Hiperkalemiain Dialysis and Non Dialysis Patiens with Acute Miocardial Infarction. Aha Journal, vol 7, http: // aroutcomes. ahajournals. org /, 22 Juni 2016.

Guyton, A. C., \& Hall, J.E. (2008). Buku Ajar Fisiologi Kedokteran. Edisi 11. Jakarta: EGC.

Hananto A. (2006). Penyakit Kardiovaskuler. Jakarta: EGC.

Hidayat, A. (2009). Metode Penelitian Keperawatan dan Teknik Analis Data. Jakarta: Salemba Medika.

Horne, M. M., \& Swearingen, L. P. (2001). Keseimbangan Cairan Elektrolit dan Asam Basa Edisi 2. Jakarta: Penerbit Buku Kedokteran EGC.

Hudak, C. M., \& Gallo, B. M. (2012). Keperawatan Kritis Pendekatan Holistik Volume 1. Alih bahasa
Nike Budhi Subekti. Jakarta: EGC.

Irianto, K. (2014). Gizi Seimbang dalam Kesehatan Reproduksi. Bandung : Alfabeta.

Kasron. (2012). Buku Ajar Anatomi Fisiologi Kardiovaskuler. Yogyakarta: Nuha Medika.

Kee, J. L. (2006). Buku Saku Pemeriksaan Laboratorium dan Diagnostik dengan Implikasi Keperawatan Edisi 2. Jakarta: EGC.

Muttaqin, A.(2009). Buku Ajar Asuhan Keperawatan Klien dengan Gangguan Sistem Kardiovaskuler dan Hematologi. Jakarta: Salemba Medika.

Nazar, I., Sutisna H., Wirasmi M. (2010). Buku Ajar Patologi II edisi I. Jakarta: Sagung Seto.

Nursalam. (2013). Konsep Penerapan Metode Penelitian Ilmu Keperawatan. Jakarta: Salemba Medika.

Prasetya, Rendi Dwi., Masrul Syafri., Efrida. (2014). Gambaran Kadar Troponin $T$ dan Creatinin Kinase Miocardial Band pada Infark Miokard Akut. Andalas Journal of Health, Vol 3,http://Jurnal.fk.unad.ac.id, $\quad 10$ Januari 2016.

Price, S. A. \& Wilson, L. M. (2005). Patofisiologi : Konsep Klinis Proses - Proses Penyakit Edisi 6 Volume 1 dan 2. Jakarta : EGC.

Rully, M. A. (2009). Jurnal: Sindroma Kardio Renal. Bandung: FK UNPAD. Sastroasmoro, S., \&Madiyono.(1994). Kardiologi Anak. Jakarta: IDAI. 
Smeltzer, S. C., \& Brenda, G. B. (2006). Keperawatan Medikal Bedah 2, Edisi 8. Jakarta: EGC.

Sodeman, W.A., \& Sodeman, T.M. (1995). Sodeman Patofisiologi. Edisi 7. Jilid II. Penerjemah: Andry Hartono. Jakarta: Hipokrates.

Sudoyo, A.W., Bambang, S., \& Idrus, A. (2009). Buku Ajar Ilmu Penyakit Dalam. Jakarta: Interna Publishing.

Sugiyono. (2012). Metode Penelitian Kuantitatif, Kualitatif, dan $R \& D$. Cetakan ke 17. Bandung: Alfabeta.

Sukardi. (2004). Metodologi Peneitian Pendidikan. Jakarta: BumiAksara.

Tamsuri, A. (2009). Klien Gangguan Keseimbangan Cairan dan Elektrolit. Jakarta: Penerbit Buku Kedokteran EGC.

Tang, Qing., Qi Hua. (2011). Relationship between Hyponatremia and In Hospital Outcome in Chinese Patients with ST Elevation Miocardial Infarction. Internal Medicine, Vol 50.

Tsani, Fitri Rusydiana. (2013). Hubungan Antara Faktor Lingkungan dan Perilaku dengan Kejadian Penyakit Jantung Koroner. Unnes Journal of Public Health, Vol 3, http://Journal.unnes.ac.id/sju/inde X.php/ujph, 21 Juni 2016.

Udjianti, W. J. (2011). Keperawatan Kardiovaskuler. Jakarta : Salemba Medika. Weinstock, D. (2010). Rujukan Cepat di Ruang ICU/ICCU. Jakarta : EGC. Widianto, Budi., L. S. Yamin.
(2014). Terapi Oksigen terhadap Perubahan

Saturasi Oksigen melalui Pemeriksaan Oksimetri pada Pasien InfarkMiokard Akut. Jurnal unimus, vol 2, http://jurnal.unimus.ac. Id / index.php/psn12012010，22 Juni 2016.

World Health Organization. (2015). Cardiovasculer Disease (CVD). http://www.who.int di akses 10 Januari pukul 11.49 WIB .

Yaswir, R., \& Ira, F. (2012). Jurnal Fisiologi dan Gangguan Keseimbangan Natrium, Kalium dan Klorida serta Pemeriksaan Laboratorium. Diakses 11 Januari 2015 dari http://jurnal.fk.unand.ac.id.

Zafar, A. M. (2015). Myocardial Infarction. http://www.emedicini.medscape/ar ticle/, diakses 12 Januari 2015. 